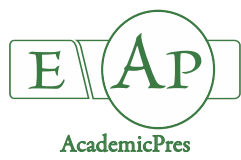

Available online: www.notulaebotanicae.ro

Print ISSN 0255-965X; Electronic 1842-4309

Not Bot Horti Agrobo, 2019, 47(2):359-367. DOI:47.15835/nbha47111274

Original Article

\title{
Antioxidant and Anticancer Properties of Leaf and Fruit Extracts of the Wild Raspberry (Rubus idaeus L.)
}

\section{Bojana VELJKOVIĆ ${ }^{1 *}$, Nataša ĐORĐEVIĆ ${ }^{1}$, Zana DOLIĆANIN ${ }^{1}$, Braho LIČINA ${ }^{1}$, Marina TOPUZOVIĆ ${ }^{2}$, Milan STANKOVIĆ ${ }^{2}$, Nenad ZLATIĆ ${ }^{2}$, Zora DAJIĆ-STEVANOVIĆ 3}

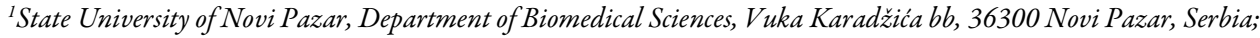 \\ bojana.radulovic@yahoo.com;bradulovic@np.ac.rs(*correspondingauthor);natasa.djordjevic@gmail.com;zana_dolicanin@yahoo.com; \\ licinabraho@live.com \\ ${ }^{2}$ University of Kragujevac, Faculty of Sciences, Institute for Biology and Ecology, Radoja Domanovića 12, 34000 Kragujevac, Serbia; \\ marina@kg.ac.rs; mstankovic@kg.ac.rs;nzlatic@gmx.com \\ ${ }^{3}$ University of Belgrade, Department of Agrobotany, Nemanjina 6, 11080 Zemun-Belgrade, Serbia; dajic@agrif.bg.ac.rs
}

\begin{abstract}
In this study the leaves and fruits of wild raspberry (Rubus idaeus L.) populations from the central Balkan region were examined to determine the level of secondary metabolites and related antioxidant activity, as well as biological activity, upon existing ethnobotanical evidence, primarily linked to gastrointestinal disorders. The values obtained for total phenols ranged from 59.68 to $96.83 \mathrm{mg} \mathrm{GA} \mathrm{g}^{-1}$ and 24.29 to $38.71 \mathrm{mg} \mathrm{GA} \mathrm{g}^{-1}$ in leaf and fruit extracts, respectively. The highest values of tannins and anthocyanins were determined for leaf extracts from a population of east Serbia at a level of $1.27 \mathrm{mg} \mathrm{mL}^{-1}$ and 9.00 $\mathrm{mg} \mathrm{mL} \mathrm{m}^{-1}$. Antioxidant activity was evaluated by measuring the scavenging capacity of the extracts on DPPH. Higher antioxidant activity was detected in the leaf extracts than in the fruit extracts. Leaf and fruit extract were the most effective against Escherichia coli (ATCC 8739). Anticancer activity was studied on a human colorectal cancer cell line HCT-116. Leaf extracts exhibited anticancer activity with $\mathrm{IC}_{50} / 24 \mathrm{~h} 162.38 \mu \mathrm{g} \mathrm{mL} \mathrm{L}^{-1}$ and $\mathrm{IC}_{50} / 48 \mathrm{~h} 95.69 \mu \mathrm{g} \mathrm{mL}^{-1}$. Wild raspberry leaf and fruit extracts contain numerous secondary metabolites providing marked antioxidant, antimicrobial and anticancer activity.
\end{abstract}

Keywords: biological activity; methanolic extracts; phytochemical analysis; secondary metabolites

\section{Introduction}

Plant secondary metabolites, mainly phenolic compounds, are characterized by strong biological activity. There are four main classes of polyphenols: flavonoids, phenolic acids, lignans, and tannins (Rao and Snyder, 2010), presented in fruits and vegetables, which are linked to particular nutritional and health benefits (Wang and Lin, 2000; Seeram, 2008). These compounds possess a capacity for scavenging of reactive oxygen species (ROS), thus exhibiting an antioxidant activity (Cao et al., 1997; Trivedi et al., 2016). Biological activity of various fruit berries, including raspberries, is attributed to the high content of anthocyanins (e.g. cyanidin 3-glucoside, cyanidin 3rutionoside, pelargonidin 3-glucoside), flavonols (quercetin, kaempferol), tannins, phenolic acids (e.g. ellagic acid), and lignans (Seeram et al., 2006; Gramza-Michalowska et al., 2017). Composition and concentration of phenolic compounds in berries and related antioxidant activity and other biological effects, are highly dependent on fruit maturity, agro-environmental conditions and post-harvest technologies (Bobinaité et al., 2012).

The genus Rubus is one of the largest in the family Rosaceae with about 700 species, being divided into 12 subgenera of which are only a few species cultivated. Ideobatus subgenus includes raspberries, which are widespread in Asia, Europe, Africa and North America. This subgenus is comprised of approximately 200 species (Marulanda et al., 2007). Modern raspberry cultivars are derived from the European red raspberry ( $R$. idaeus L.), North American red raspberry ( $R$. strigosus Michx.), the black raspberry $(R$. occidentalis L.) and the purple raspberries $(R$. neglectus Peck) that are hybrids between red and black raspberries (Castillo, 2006). Most of commercial varieties are hybrids developed by breeding of the wild raspberries (Çekiç and Özgen, 2010). 
360

The wild R. idaeus in region of Balkans and Serbia grows on altitudes above $1000 \mathrm{~m}$ a.s.l., mainly on the edge of beech forests, as well as in vineyards, extensive orchards, hedges, pastures and in abandoned meadows and other undermanaged habitats (Dujmović Purgar et al., 2012).

Biological activity of the raspberry fruit, such as antimicrobial (Rauha et al., 2000), anticancer (Baby et al., 2017), antioxidant (Kong et al., 2003), as well as prevention of cardiovascular diseases and type II diabetes (Rao and Snyder, 2010), is linked to various phenolic compounds, such as hidroxycinnamic acid, gallic acid, galloyl esters, ellagic acid conjugates, flavonols, and anthocyanins (MäättäRiihinen et al., 2004). Because of rich phenolic profile and high concentration of vitamin C (Benvenuti et al., 2004), the raspberry belongs to a group of fruit of high antioxidant capacity (Beekwilder et al., 2005; Jakobek et al., 2009).

Leaf is less studied than fruit, and most of reports mainly referrers to phytochemical composition (Gudej and Tomczyk, 2004), while the biological effects are most related to fruit, probably because of wide use of fruit in human nutrition (Rauha et al., 2000).

The leaves of wild and cultivated raspberry are listed in traditional Balkan and Southeast European medicine, with evidence of use for relief of morning sickness during pregnancy, preventing miscarriage and easing labour pains (Patel et al., 2004), in addition to ethnobotanical notes on antimicrobial and anticancer effects of it fruit (Rauha $e t$ al., 2000; Seeram et al., 2006). Study of Çekiç and Özgen (2010) pointed out the better antioxidant properties of the wild raspberry in comparison of the standard (cultivated) varieties, which was related to higher content of the total phenolic compounds and organic acids. However, there are still missing data on biological activity and medicinal uses of the raspberry (Holst et al., 2004), especially referring to wild populations.

The present study aims to determine the variability of main groups of secondary metabolites in different wild raspberry populations, collected from the central Balkan region, as well as to assess some related biological effects of its fruits and leaves, including antioxidant, antibacterial (studied on the bacterial strains of gut microbiota differing in pathological potential) and anticancer effects using human colorectal cancer cell line HCT-116 model.

\section{Materials and Methods}

\section{Plantmaterial}

Plant material (leaves and fruits) of wild raspberry $(R$. idaeus) was collected during field research in the period June - August 2016. The material was collected in the mountainous region of Serbia from seven different sites: Golija (P1), Kopaonik (P2), Goč (P3), Studena Mountain (P4), Zeljin (P5), Ozren (P6) and Stara Mountain (P7) (Table 1). Leaf and fruit material was collected as bulk sample of at least 20 individuals of each population.

\section{Chemicals}

All the reagents used in this study were analytical grade and were obtained from Sigma Chemical Company (St. Louis, USA) and Merck (Darmstadt, Germany).
Table 1. Geographical position of the localities

\begin{tabular}{ccc}
\hline Locality & GPS & Elevation $(\mathrm{m})$ \\
\hline P1 & N- 43.19140735 & 1432 \\
& E- 20.25105463 & \\
P2 & N- 43.18337160 & 1985 \\
& E- 20.49538319 & \\
P3 & N- 43.57179799 & 675 \\
& E- 20.73005118 & \\
P4 & N- 43.51729933 & 983 \\
& E- 20.64440374 & \multirow{2}{*}{1357} \\
P5 & N- 43.47037465 & \\
& E- 20.82764226 & 931 \\
P6 & N- 43.36538238 & 1710 \\
& E- 21.53281832 & \\
P7 & N- 43.361622 & \\
& E- 22.578614 &
\end{tabular}

P1 - Golija; P2 - Kopaonik; P3 - Goč; P4 - Studena Mountain; P5 - Željin; P6 - Ozren; P7 - Stara Mountain

\section{Preparation of methanolic fruit and leaf extracts}

Plant material (10 $\mathrm{g}$ of fresh leaves and fruits) was transferred to dark bottles to which $200 \mathrm{~mL}$ of methanol was added and the sample was stored at room temperature. After 24 hours, the content was filtered through Watman filter paper and the residue was then added to the same solvent volume. After 48 hours the procedure was repeated. Process of extraction was performed in a dark room. The combined supernatant was then evaporated using a vacuum evaporator at $40{ }^{\circ} \mathrm{C}$. The samples were then stored in a refrigerator until use for biochemical analyses at a temperature of $4^{\circ} \mathrm{C}$.

\section{Phytochemical analyses of plant extracts and antioxidant activity \\ Determination of total phenolic content}

Spectrophotometric method was used to determine the overall phenol concentration (Wootton-Beard et al., 2011). The reaction mixture was prepared by mixing $0.5 \mathrm{~mL}$ of the prepared methanolic solution of the extract $\left(1 \mathrm{mg} \mathrm{mL}^{-1}\right), 2.5$ $\mathrm{mL}$ of $10 \%$ water-soluble Folin-Ciocalteu reagent and 2.5 $\mathrm{mL} 7.5 \% \mathrm{NaHCO}_{3}$. The samples were then incubated at 45 ${ }^{\circ} \mathrm{C}$ for 15 minutes. Blank was prepared in the same way, only methanol was added instead of the extract. The absorbance of the samples and the blank (methanol instead of extract solution) was measured on the spectrophotometer $\lambda_{\max }=765 \mathrm{~nm}$ (Jenway 6105; Bibby Scientific Limited, Staffordshire, UK). The same procedure was repeated for gallic acid (GA) to calculate the equivalent concentration of total phenols ( $\mathrm{mg} \mathrm{GA} \mathrm{g}^{-1}$ of extract).

\section{Determination of flavonoid concentrations}

A spectrophotometric method was used to determine the flavonoid concentration (Quettier-Deleu et al., 2000). The samples were prepared by mixing $1 \mathrm{~mL}$ of the methanolic solution of the extract $\left(1 \mathrm{mg} \mathrm{mL}^{-1}\right)$ and $1 \mathrm{~mL}$ of $2 \% \mathrm{AlCl}_{3}$ dissolved in methanol. The samples were incubated for an hour at room temperature. The absorbance was measured at $\lambda_{\max }=415 \mathrm{~nm}$. The same procedure was repeated for rutin $(\mathrm{Ru})$ to calculate the equivalent concentration of flavonoids ( $\mathrm{mg} \mathrm{Ru} \mathrm{g}^{-1}$ of extract). 


\section{Determination of tannins concentration}

The total amount of tannins was determined by spectrometry measurement (Hosu et al., 2014). The samples were prepared by mixing $2 \mathrm{~mL}$ of the extract, $3 \mathrm{~mL}$ of concentrated $\mathrm{HCl}$ and $1 \mathrm{~mL}$ of distilled water.

The content of the first sample was incubated for 30 min at $100{ }^{\circ} \mathrm{C}$ whereas $0.5 \mathrm{~mL}$ of ethanol was added to the second sample.

The absorbance of the samples was determined at wavelengths $\lambda_{\max }=470,520$ and $570 \mathrm{~nm}$. The differences $(\Delta \mathrm{A})$ between the samples values obtained were determined at the same wavelengths $(\Delta \mathrm{A} 470, \Delta \mathrm{A} 520, \Delta \mathrm{A} 570)$. The values for wavelengths $\Delta \mathrm{A} 470, \Delta \mathrm{A} 520$ and $\Delta \mathrm{A} 570$ were calculated as follows: TTC $(\mathrm{g} / \mathrm{L})=15.7 \times$ minimum $(\Delta \mathrm{A} 520)$.

\section{Determination of anthocyanins concentration}

Samples containing $0.5 \mathrm{~mL}$ of extract, $0.5 \mathrm{~mL}$ of $0.1 \%$ ethanolic $\mathrm{HCl}$ solution and $10 \mathrm{~mL}$ of $2 \%$ aqueous $\mathrm{HCl}$ solution were used to determine the total amount of anthocyanins. The procedure was as follows: $4.4 \mathrm{~mL}$ of distilled water was added to the first sample, while $4.4 \mathrm{~mL}$ of $13 \%$ sodium bisulphate was added to the second sample and diluted at a ratio of $1: 1$.

The absorbance of the samples was determined at a wavelength of $\lambda_{\max }=520 \mathrm{~nm}$ using a starting solution made up of $4.9 \mathrm{~mL}$ distilled water, $0.5 \mathrm{~mL}$ of $0.1 \%$ ethanolic $\mathrm{HCl}$ solution and $10 \mathrm{~mL}$ of $2 \%$ aqueous $\mathrm{HCl}$ solution. The values obtained $(\Delta \mathrm{A})$ were multiplied by the coefficient 875. The total amount of anthocyanins in a sample is expressed in $\mu \mathrm{g} \mathrm{mL} \mathrm{L}^{-1}$ of the extract (Hosu et al., 2014).

\section{Evaluation of DPPH scavenging activity}

Antioxidant activity (AOA) was measured using DPPH method according to Takao et al. (1994). Process of analysis was performed in a dark room. The procedure was as follows: for this method, a solution of 2.2-diphenyl-1picrylhydrazyl (DPPH) in methanol $\left(80 \mu \mathrm{g} \mathrm{mL}^{-1}\right)$ was used. The test sample solution (extract) in methanol was at a concentration of $1000 \mu \mathrm{g} \mathrm{mL}$, as were the solutions of positive control (vitamin C and butyl hydroxytoluol-BHT). The concentrations tested were $1000 \mu \mathrm{g} \mathrm{mL}^{-1}, 500 \mu \mathrm{g} \mathrm{mL}^{-1}$, $250 \mu \mathrm{g} \mathrm{mL}^{-1}, 125 \mu \mathrm{g} \mathrm{mL}^{-1}, 62.5 \mu \mathrm{g} \mathrm{mL}^{-1}, 31.25 \mu \mathrm{g} \mathrm{mL}^{-1}$ and $15.625 \mu \mathrm{g} \mathrm{mL}^{-1}$. In 6 tubes, $2 \mathrm{~mL}$ of methanol was measured, then $2 \mathrm{~mL}$ of the initial concentration extract $(1000 \mu \mathrm{g} \mathrm{mL}$ $\left.{ }^{1}\right)$ was added to the first tube and a series of double dilutions was prepared in the other tubes.

The same preparation was carried out for the positive controls. Then, $2 \mathrm{~mL}$ of DPPH solution was added to each tube and they were incubated for $30 \mathrm{~min} / \mathrm{RT} /$ in a dark place. The reading of the absorbance was carried out at $\lambda=$ $725 \mathrm{~nm}$. For each sample, three absorbencies were measured and the mean value was calculated. A control (blank) was prepared by measuring $2 \mathrm{~mL}$ of methanol in one tube, adding $2 \mathrm{~mL}$ of DPPH solution and then incubating it for $\mathrm{min} / \mathrm{RT} /$ in a dark place. The reading of the absorbance was at $\lambda=725 \mathrm{~nm}$.

For each sample, three absorbencies were measured and the mean value calculated. On the basis of the results, the $\mathrm{IC}_{50}$ concentration was determined.
Biological activity

Screening of antimicrobial activity for selected gut microbiota

Test microorganisms

The antimicrobial activity of the methanolic extracts of the leaves and fruits of wild raspberry, were tested against a panel of ATCC (American Type Culture Collection) microorganisms, including Gram-positive Sarcina lutea (ATCC 9431) and Bacillus subtilis (ATCC 6633) and Gram-negative Escherichia coli (ATCC 8739). Three selected microorganisms are parts of normal human gut microbiota, differing among each other in term of effects on gastro-intestinal functionality. The $B$. subtilis is known as non-pathogenic bacteria, often used in probiotics. The $S$. lutea was selected as possibly pathological gastric bacteria known to be frequent in foodborne infections and intoxications, related to gastric obstruction and gastric disorders (Lam-Himlin et al., 2012), while for selected pathogenic strains of $E$. coli, including the one which we used in the current study it is known the role in gastric disorders (Rowe, 1979). There are some recent reports on linkage between gut microbiome and colorectal cancer (Sun and Kato, 2016), including the role of E. coli (Khan et al., 2017).

\section{Microdilution method}

Antimicrobial activity was tested by determining the minimum inhibitory concentration (MIC) and minimum bactericidal concentration (MBC) using the microdilution method (Sarker et al., 2007). Stock solutions of the extracts were prepared in pure dimethyl sulfoxide (DMSO). The concentration of the stem of the herbal extracts tested was $40 \mathrm{mg} / \mathrm{mL}$. A double dilution of the plant extracts was made in 96-well plates containing Mueller-Hinton broth for bacteria. The tests concentrations ranged from $20 \mathrm{mg}$ $\mathrm{mL}^{-1}$ to $0.16 \mathrm{mg} \mathrm{mL}^{-1}$. The final concentration was $5 \mathrm{X} 105$ $\mathrm{CFU} \mathrm{mL} \mathrm{mL}^{-1}$. Bacterial growth was monitored by the addition of ressaurin, a bacterial growth indicator. As positive control doxycycline was used. The plates were incubated for 24 hours at $37{ }^{\circ} \mathrm{C}$. The MIC is defined as the lowest concentration of the test substance that causes the resusurin to change color from blue to pink. The minimum bactericidal activity was determined by transferring $10 \mu \mathrm{L}$ of plaque samples whereby no color change was observed on the nutrient agar. At the end of incubation, the lowest concentration without bacterial growth is defined as the minimum bactericidal concentration. All tests were performed in triplicate.

\section{Anticancer activity}

\section{Cell cultures and treatment}

For testing the anticancer activity of the plant extracts we used the human colorectal cancer cell line HCT-116, purchased from the American Type Culture Collection (ATCC, Manassas, VA, USA). The cells were cultured in DMEM (Dulbecco's Modified Eagle Medium) (Gibco, USA) and supplemented with $10 \%$ fetal calf serum, penicillin $\left(100 \mathrm{IU} \mathrm{mL}^{-1}\right)$ and streptomycin $\left(100 \mu \mathrm{g} \mathrm{mL}^{-1}\right)$ at $37^{\circ} \mathrm{C}$ in a $5 \% \mathrm{CO}_{2}$ humidified atmosphere. 
362

The cell viability and proliferation were determined at $80 \%$ to $85 \%$ confluence using the MTT assay. For the MTT assay, the cells were seeded in a 96 -well plate $\left(10^{4}\right.$ cells per well) and incubated for $24 \mathrm{~h}$ at $37^{\circ} \mathrm{C}$ in a humidified atmosphere containing $5 \% \mathrm{CO}_{2}$. After 24 hours, the medium was replaced with $100 \mu \mathrm{L}$ solutions of various concentrations of the plants extracts. Stock solutions of the extracts were made in dimethyl sulfoxide (DMSO) at a concentration of $200 \mu \mathrm{g} \mathrm{mL}$. The final concentration of DMSO in the stock solutions was $1 \%(\mathrm{v} / \mathrm{v})$. The stock solutions were serially diluted 2-fold, in concentrations ranging from $200 \mu \mathrm{g} \mathrm{mL}^{-1}$ to $6.33 \mu \mathrm{g} \mathrm{mL}^{-1}$ in the DMEM medium. Untreated cells were used as controls. Cells with the treatment were incubated at $37{ }^{\circ} \mathrm{C}$ and $5 \% \mathrm{CO}_{2}$ in a humidified atmosphere for $24 \mathrm{~h}$ and $48 \mathrm{~h}$. The control and each of the extracts were tested in triplicate in three independent tests.

\section{Cell viability and proliferation assay (MTT assay)}

After $24 \mathrm{~h}$ and $48 \mathrm{~h}$ of treatment, the cell viability and proliferation were determined using the MTT assay (Mosmann, 1983). The MTT assay is based on the reduction of yellow tetrazolium salt MTT (3-[4,5dimethylthiazol-2-yl]-2,5-diphenyltetrazolium bromide) by the mitochondrial dehydrogenase of living cells to purple formazan that is soluble. After the incubation period, the medium with the treatments was removed and $100 \mu \mathrm{L}$ of the MTT solution at a final concentration $5 \mathrm{mg} \mathrm{mL}^{-1}$ was added to each well and incubated in a $5 \% \mathrm{CO}_{2}$ humidified atmosphere at $37^{\circ} \mathrm{C}$ for $3 \mathrm{~h}$. After incubation, the MTT solution was discarded and the colored crystals of formazan that were produced were dissolved in $150 \mu \mathrm{L}$ of DMSO. The absorbance values were measured on a microplate reader at $550 \mathrm{~nm}$. The cell viability was calculated as the ratio of absorbance of the group treated divided by the absorbance of control group and multiplied by 100 to give the percentage of viability.

The data were expressed as the means \pm standard errors (S.E.). The effects of the plant extracts were expressed by $\mathrm{IC}_{50}$ (the half-maximal growth inhibitory concentration). The $\mathrm{IC}_{50}$ values were calculated from the dose curves by a computer program (CalcuSyn).

\section{Statistical analysis}

Statistical analyses were performed with the software packages SPSS for Windows (version 10.0). All measurements were carried out in triplicate, and the results are presented as mean \pm S.E.M. Statistical analysis was performed via linear correlation coefficient and Pearson's correlation coefficient.

\section{Results and Discussion}

\section{Phytochemical analyses}

Results of phytochemical analyses are presented in Table 2. Total phenolic compounds of leaf methanolic extracts ranged from 59.68 to $96.83 \mathrm{mg} \mathrm{GA} \mathrm{g}^{-1}$. The lowest values were recorded in the samples from the P1 study site, while the highest values were found for samples of populations assigned as P4 and P7. Sample of P7 population had a slightly lower concentration than sample from P4 (95.50 $\mathrm{mg} \mathrm{GA} \mathrm{g}{ }^{-1}$ ). The concentration of phenolic compounds of wild raspberry fruits ranged from $24.29 \mathrm{mg} \mathrm{GA} \mathrm{g}^{-1}$ (P5 population) to $38.71 \mathrm{mg} \mathrm{GA} \mathrm{g}^{-1}$ (P7). The lowest values of total phenolic content were recorded in samples taken from shadowy sites (P5 and P3), while the highest values had samples from sunny localities and higher altitudes. Previous studies ascertained significant correlation between production of secondary metabolites in plants and enhancement of plant protective mechanisms. Namely, plants produce larger quantities of secondary metabolites so as to efficiently protect protein synthesis from adverse effects of UV radiation that is particularly intense at higher altitudes (Duval et al., 1999). Taking into account that environmental factors influence plant metabolism reactions, Mikulić-Petkovsek et al. (2012) suggested that a higher content of phenols in the wild berries comparing with the cultivated ones, could be a result of adaptive mechanism, allowing growth of wild berry in their harsh natural environment.

The flavonoid concentration in studied wild raspberry leaf samples ranged from $7.02 \mathrm{mg} \mathrm{Ru} \mathrm{g}^{-1}$ (P7 population), to $7.53 \mathrm{mg} \mathrm{Ru} \mathrm{g}^{-1}$ (P1). Concentration of flavonoid values in the leaf extracts was fairly uniform. The content of flavonoids in leaves of the wild and cultivated raspberry was reported by Gudej and Tomczyk (2004), who concluded that raspberries are a rich source of flavonoids, ellagic acid and tannins. In the fruit extracts of the wild raspberry, the flavonoid concentration ranged from $4.39 \mathrm{mg} \mathrm{Ru} \mathrm{g}^{-1}$ as recorded in sample of $\mathrm{P} 3$ population, up to $4.97 \mathrm{mg} \mathrm{Ru} \mathrm{g}^{-1}$, recorded for P2 population. Similar values of flavonoids ( 6.0 $\mathrm{mg} \mathrm{g}^{-1}$ fresh weight) in raspberry fruits were recorded in study of Rauha et al. (2000). The highest concentrations of the total flavonoids in the raspberry fruit were found in one wild ecotype among different samples of domesticated and wild grown raspberries in Turkey (Gülçin et al., 2011).

The concentration of total tannins in the methanol extracts of wild raspberry leaves ranged from $0.73 \mathrm{mg} \mathrm{mL}^{-1}$, as recorded for the samples from P1, up to $1.27 \mathrm{mg} \mathrm{mL}^{-1}$, in population P7. Results on tannin leaf concentration are similar to those reported by Durgo et al. (2012). In the fruit extracts, tannin concentration ranged from $0.20 \mathrm{mg} \mathrm{mL}^{-1}$ (P5) to $0.45 \mathrm{mg} \mathrm{mL}^{-1}$ (P3). In colored fruits, which are rich in anthocyanins, tannins stabilize the anthocyanins by linking them to form copolymers (Lopes da Silva et al., 2007). Berries rich in anthocyanins or their derived extracts exhibit numerous protective effects with potential benefits for human and animal health (Konić-Ristić et al., 2011). The red fruits have a higher content of cyanide-based glycosides, while the dark colored fruits contained more delphinidine glycosides. There are no significant differences in the anthocyanin composition between the cultivated and wild-growing fruits of individual species (Veberić et al., 2015). The concentration of anthocyanins in the methanolic leaf extracts ranged from 4.43 to $9.00 \mu \mathrm{g} \mathrm{mL}^{-1}$. The highest concentration was recorded in the of P6 population, while the lowest was recorded in P5 population. The highest concentration of anthocyanins in the methanol extracts of the fruit was observed in samples from P1 site $\left(4.73 \mu \mathrm{g} \mathrm{mL}{ }^{-1}\right.$ ), while the lowest was observed for P5 population $(0.31 \mu \mathrm{g} \mathrm{mL}$ ). Wang and Lin (2000) have shown that the concentration of the total anthocyanins increases with the degree of maturity of the fruits, and their results are in line with values determined in our study for mature fruits which were evaluated. 
Measurements of antioxidant activity (AOA) were performed using the free radical (DPPH) assay. The results are expressed as an $\mathrm{IC}_{50}$ concentration, and $\mathrm{AOA}$ is inversely proportional to the numerical value of the $\mathrm{IC}_{50}$ values. The results of the AOA extract of the leaves ranged from 110.17 to $199.18 \mu \mathrm{g} \mathrm{mL}$. The highest AOA was detected in the leaf extract from P7 population. The methanol extracts from $\mathrm{P} 3$ and $\mathrm{P} 4$ site were also characterized by high values of $\mathrm{AOA}$. The similar data were obtained by Durgo et al. (2012) indicating the high antioxidative potential of raspberry leaf extracts. Therefore, raspberries can be added to tea blends to increase the antioxidant capacity of the beverages for a better effect on human health. The AOA methanol extract of the fruit ranged from 246.09 to $489.60 \mu \mathrm{g} \mathrm{mL}^{-1}$. The highest AOA was shown for methanol extracts of wild raspberry fruit from P7 site, while the lowest values were from the samples of the P5 population. Upon obtained results, it seems that fruits of wild raspberry from the higher and sunny mountains are better source of natural antioxidants (P7 and $\mathrm{P} 4)$. Our results are in a line with some previous studies which showed that the extracts of the samples collected at higher altitudes had greater antioxidant capacity than the extracts of the samples taken at lower altitudes (Ghasemi $e t$ al., 2011). Tosun et al. (2009) showed that wild raspberry genotypes, compared with cultivated varieties, had a higher content of total phenols, a higher concentration of ascorbic acid and better AOA. By comparing the AOA of leaves and fruits, it can be seen that the leaves had a higher level of AOA. Based on this, it can be concluded that the antioxidant capacity is specific to the type of tissue due to different phytochemical content of bioactive antioxidant compounds (Wang and Lin, 2000). The antioxidant activity was significantly higher in the leaves than in fruits of the wild raspberry populations, which is correlated with total phenolics content, including flavonoids, tannins, and anthocyanins, similarly to results obtained for some berry fruits (Vyas et al., 2013). Leaf extracts from P1, P2 and P6 populations had the higher content of flavonoids while the other populations had more total phenols. In the case of fruit extracts, the P1 population with the high content of secondary metabolites is separated (high content of the total phenols and anthocyanins, but also a high content of tannins and flavonoids). Populations P2 and P4 exhibited a high content of flavonoids while population P3 had the highest tannins content.

Among the values of phenolic components and AOA obtained it is possible to examine the statistical dependence of the method of linear regression. The correlation coefficient (R), as well as the coefficient of determination $\left(R^{2}\right)$, which show how much of the variation of the dependent variables explains the model for AOA related to the total phenols, flavonoids, tannins and anthocyanins (Table 3). As reported previously, all studied compounds, primarily phenols are highly related to express AOA (Stanković et al., 2015). A relatively strong and weak link between content of total phenolics and flavonoids respectively implies the possibility that other classes of phenolic secondary metabolites, aside from flavonoids, contribute to antioxidant activity in raspberry. Former studies on major secondary metabolites in fruits and leaves of the $R$. idaeus revealed the presence of ellagic, p-coumaric, ferulic acid and quercetin (Jacobek et al., 2009). Significant biological activity of these phenolic acids and flavonoids has already been confirmed for antioxidant activity of these compounds (Kadoma and Fujisawa, 2008). Also, tannins and flavonoid content showed strong correlation coefficient (0.847 and 0.838) with AOA. Based on these statistical data, it can be seen that phenolic compounds are the dominant components contributing to $\mathrm{AOA}$, which is in agreement with range of previous reports.

\section{Biological activity}

The test results of antimicrobial activity are presented in the Table 4. The methanolic extract samples of the leaves from all of the populations showed a mean inhibitory activity between 2.5 and $20.00 \mathrm{mg} \mathrm{mL}^{-1}$. The E. coli exhibited the highest sensitivity to the studied extracts, in range from 2.50 to $10.00 \mathrm{mg} \mathrm{mL}^{-1}$, while the most resistant was Gram-positive bacteria B. subtilis with MIC from 10.00 to $20.00 \mathrm{mg} \mathrm{mL}^{-1}$. The methanolic extracts of the fruits also showed a mean inhibitory activity of 5.00 to $20.00 \mathrm{mg} \mathrm{mL}^{-1}$,

Table 2. Total phenolic content ( $\mathrm{mg} \mathrm{GA} \mathrm{g}^{-1}$ of extract), flavonoid concentration ( $\mathrm{mg} \mathrm{Ru} \mathrm{g}{ }^{-1}$ of extract), tannins ( $\mathrm{mg} \mathrm{mL}^{-1}$ of extract), total anthocyanins ( $\mu \mathrm{g} \mathrm{mL} \mathrm{m}^{-1}$ of extracts), and antioxidant activity expressed in terms of $\mathrm{IC}_{50}$ values $\left(\mu \mathrm{g} \mathrm{mL}^{-1}\right)$

\begin{tabular}{ccccccc}
\hline Sample & Population & $\begin{array}{c}\text { Total phenolic } \\
\text { content }\end{array}$ & $\begin{array}{c}\text { Flavonoid } \\
\text { content }\end{array}$ & $\begin{array}{c}\text { Tannin } \\
\text { content }\end{array}$ & $\begin{array}{c}\text { Total anthocyanin } \\
\text { content }\end{array}$ & $\begin{array}{c}\text { Antioxidant } \\
\text { activity }\end{array}$ \\
\hline \multirow{6}{*}{ Leaf } & P1 & $59.68 \pm 1.40$ & $7.53 \pm 0.06$ & $0.73 \pm 0.031$ & $8.61 \pm 1.05$ & $199.18 \pm 1.12$ \\
& P2 & $69.17 \pm 0.57$ & $7.39 \pm 0.17$ & $0.99 \pm 0.006$ & $7.36 \pm 0.63$ & $198.30 \pm 1.18$ \\
& P3 & $92.42 \pm 0.30$ & $7.19 \pm 0.23$ & $0.85 \pm 0.009$ & $5.90 \pm 0.46$ & $117.83 \pm 1.49$ \\
& P4 & $96.83 \pm 1.24$ & $7.27 \pm 0.15$ & $1.04 \pm 0.035$ & $6.26 \pm 0.97$ & $118.49 \pm 0.66$ \\
& P5 & $87.25 \pm 1.03$ & $7.12 \pm 0.07$ & $0.97 \pm 0.026$ & $4.43 \pm 0.75$ & $128.33 \pm 1.83$ \\
& P6 & $76.62 \pm 0.59$ & $7.37 \pm 0.19$ & $0.90 \pm 0.074$ & $9.00 \pm 1.11$ & $158.70 \pm 0.93$ \\
\hline \multirow{3}{*}{ Fruit } & P7 & $95.50 \pm 0.65$ & $7.02 \pm 0.18$ & $1.27 \pm 0.029$ & $7.46 \pm 0.93$ & $110.17 \pm 1.42$ \\
& P1 & $36.29 \pm 0.43$ & $4.93 \pm 0.27$ & $0.40 \pm 0.017$ & $4.73 \pm 0.45$ & $294.79 \pm 1.63$ \\
& P2 & $32.97 \pm 0.86$ & $4.97 \pm 0.35$ & $0.23 \pm 0.027$ & $2.63 \pm 0.24$ & $343.98 \pm 0.90$ \\
& P3 & $31.83 \pm 0.22$ & $4.39 \pm 0.32$ & $0.45 \pm 0.015$ & $2.37 \pm 0.16$ & $352.08 \pm 1.36$ \\
& P4 & $37.05 \pm 0.92$ & $4.95 \pm 0.29$ & $0.27 \pm 0.011$ & $1.45 \pm 0.34$ & $286.18 \pm 1.51$ \\
\hline
\end{tabular}


364

Table 3. R coefficient of correlation and R-square determining coefficient

\begin{tabular}{cc}
\hline $\mathrm{R}\left(\mathrm{R}^{2}\right)$ & Antioxidant activity (DPPH) \\
\hline Total phenol content & $0.923(0.852)$ \\
Flavonoid content & $0.838(0.702)$ \\
Tannin content & $0.847(0.718)$ \\
Total anthocyanin content & $0.776(0.602)$ \\
\hline
\end{tabular}

Table 4. Antimicrobial activity: minimal inhibitory concentrations (MIC) and minimal bactericidal concentration (MBC) of methanolic extracts from leaves and fruits from Rubus idaeus $\left(\mathrm{mg} \mathrm{mL}^{-1}\right)$ and antibiotic used as positive control $\left(\mu \mathrm{g} \mathrm{mL} L^{-1}\right)$

\begin{tabular}{cccccccc}
\hline \multirow{2}{*}{ Sample } & \multirow{2}{*}{ Population } & \multicolumn{2}{c}{ S. lutea } & \multicolumn{2}{c}{ B. subtilis } & \multicolumn{2}{c}{ E. coli } \\
\cline { 2 - 8 } & & MIC & MBC & MIC & MBC & MIC & MBC \\
\hline \multirow{5}{*}{ Leaf } & P1 & 2.50 & 20.00 & 10.00 & 20.00 & 2.50 & $>20.00$ \\
& P2 & 2.50 & 5.00 & 20.00 & 10.00 & 2.50 & 20.00 \\
& P3 & 5.00 & 5.00 & 10.00 & 20.00 & 2.50 & $>20.00$ \\
& P4 & 5.00 & 10.00 & 10.00 & 20.00 & 5.00 & $>20.00$ \\
& P5 & 20.00 & 20.00 & 20.00 & 10.00 & 2.50 & $>20.00$ \\
& P6 & 10.00 & 20.00 & 20.00 & $>20.00$ & 5.00 & $>20.00$ \\
& P7 & 5.00 & 20.00 & 10.00 & $>20.00$ & 10.00 & $>20.00$ \\
\hline \multirow{5}{*}{ Fruit } & P1 & 10.00 & 20.00 & 20.00 & 20.00 & 10.00 & $>20.00$ \\
& P2 & 5.00 & 20.00 & 20.00 & $>20.00$ & 10.00 & $>20.00$ \\
& P3 & 5.00 & 20.00 & 20.00 & 10.00 & 10.00 & 20.00 \\
& P5 & 5.00 & 20.00 & 20.00 & 20.00 & 10.00 & $>20.00$ \\
\hline Doxycycline & P7 & 5.00 & 20.00 & 20.00 & 20.00 & 10.00 & 20.00 \\
\hline
\end{tabular}

with the most susceptible Gram-positive bacteria $S$. lutea, while the most resistant was B. subtilus with a MIC of 20.00 $\mathrm{mg} \mathrm{mL}^{-1}$ for all samples. Rauha et al. (2000) demonstrated the moderate antimicrobial activity of the methanol extracts of raspberry fruits in relation to $B$. subtilus, while the methanolic extract of fruits exhibits mild antimicrobial activity in relation to some bacteria, including, $S$. lutea and $E$. coli, similarly to our findings. The most effective antibacterial effect was determined for the leaf extract of P1 population, which was rich in flavonoids and anthocyanins, so the raspberry leaf can be recommended in form of a hot water infusion and decoct, i.e. herbal tea in the treatments of infections. Since methanolic leaf extract did not exhibit any significant activity against Gram positive $B$. subtilis - widely used as probiotic (Liu et al., 2012), simultaneously affecting pathogenic bacteria $S$. lutea and $E$. coli, the ethnobotanical data on use of herbal tea from raspberry leaf for stabilization of the normal gut flora and diarrhea (Menković et al., 2014) treatment might be confirmed. All extracts exhibited much lower antimicrobial activities than the tested antibiotic (Table 4). During the study, the ability of methanol extracts from the leaves and fruits to inhibit the growth of human colorectal cancer cell line HCT-116 were tested. The $\mathrm{IC}_{50}$ values of leaf extracts after $24 \mathrm{~h}$ and $48 \mathrm{~h}$ are presented in Fig. 1. Methanolic extracts of raspberry leaves from P1 showed the strongest anticancer activity with $\mathrm{IC}_{50} / 24 \mathrm{~h}$ 162.38 and $\mathrm{IC}_{50} / 48 \mathrm{~h} 95.69 \mu \mathrm{g} \mathrm{mL}^{-1}$. On the other hand, leaf extracts from $\mathrm{P} 4$ did not show anticancer activity, while the leaf extracts from P7 had a mild anticancer activity after
$48 \mathrm{~h}$. It is important to note that the extracts of leaves from P7 and P4 had the highest AOA, leading to the conclusion that anticancer and AOA are not positively, but negatively correlated (Table 5). Boivin et al. (2007) reached similar conclusions, showing that strawberry juice was a very weak $\left(15 \%\right.$ at $\left.50 \mu \mathrm{mL}^{-1}\right)$ inhibitor of cancer cell proliferation, but exhibited the second highest ORAC value $(22.6 \mu \mathrm{mol}$ $\left.\mathrm{TE} \mathrm{mL}^{-1}\right)$. Strawberries were also found to have a relatively high antioxidant capacity $\left(14.6 \mu \mathrm{mol} \mathrm{TE} \mathrm{mL}^{-1}\right)$. The methanolic extracts of wild raspberry fruit have shown very low anticancer activity (Fig. 2.). Bowen-Forbes et al. (2012) examined the anticancer activity of several extracts of raspberry fruits, yielding results that indicate that only the ethanol extract shows a mild anticancer activity, while the methanolic extract has no anticancer activity, which coincides with our findings. On the other hand, this finding contradicts that of Seeram et al. (2006) according to whom increasing the concentration of extracts increases the inhibition of carcinogenic growth.

The statistical dependence between the phytochemical parameters tested in the methanol extracts of the leaves and fruits and their anticancer activity was determined on the basis of Pearson's correlation coefficient (Table 5). There are statistically significant correlations between those tested values in which Sig. $\mathrm{P}<0.05$. Positive correlations exist between MTT 24 h and total phenols (P-value $=0.001<\mathrm{P}$ critical $=0.05)$, confirming notes on an important role of natural polyphenols in cancer prevention (Huang et al., 2008).

Table 5. Pearson's correlation coefficient

\begin{tabular}{|c|c|c|c|c|c|}
\hline & MTT 24h & MTT $48 \mathrm{~h}$ & Leaf AOA (DPPH) & Leaf flavonoids & Leaf total phenol content \\
\hline MTT 24h & & & $-.882^{\prime \prime}$ & $-.787^{\circ}$ & $.950^{\prime \prime}$ \\
\hline \multicolumn{6}{|l|}{ MTT $48 \mathrm{~h}$} \\
\hline Leaf AOA (DPPH) & $-.882^{\prime \prime}$ & & & $.876^{\circ}$ & $-.973^{\prime \prime}$ \\
\hline Leaf flavonoids & $-.787^{\circ}$ & & $.876^{\prime \prime}$ & & $-.857^{\circ}$ \\
\hline Leaf total phenol content & $.950^{*}$ & & & $-.857^{\circ}$ & \\
\hline
\end{tabular}

${ }^{*}$ Correlation is significant at the 0.05 level (2-tailed). 

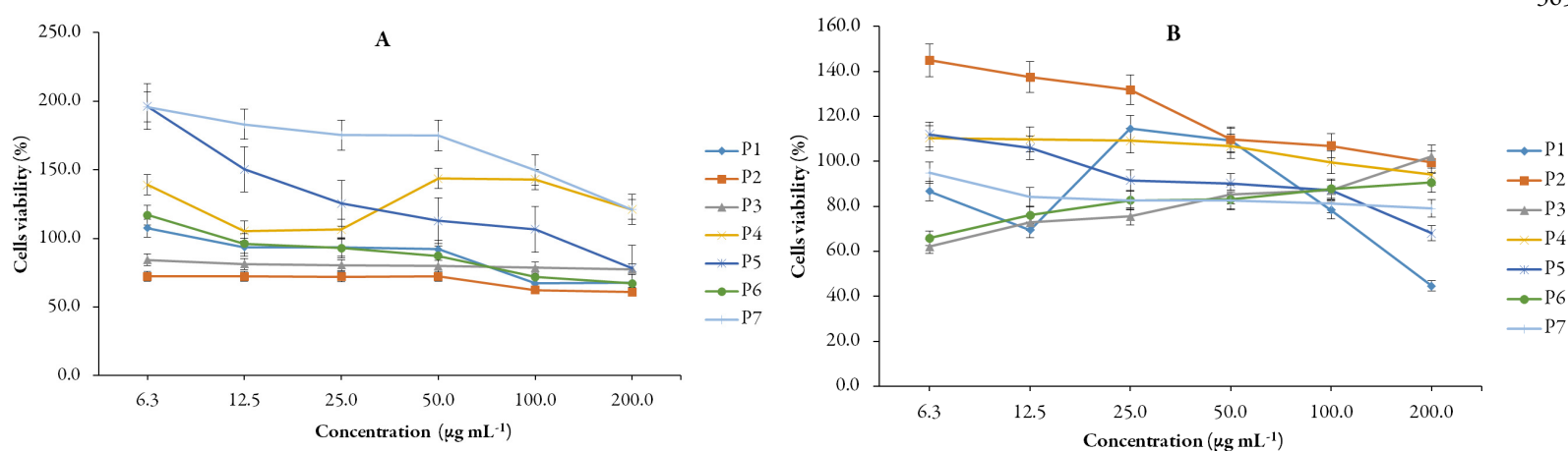

Fig. 1. Anticancer activity of methanolic leaf extracts of the wild Rubus idaeus populations: (A) $\mathrm{IC}_{50} / 24 \mathrm{~h}$; (B) $\left.\mathrm{IC}_{50} / 48 \mathrm{~h}_{(\mu \mathrm{g} \mathrm{mL}}^{-1}\right)$
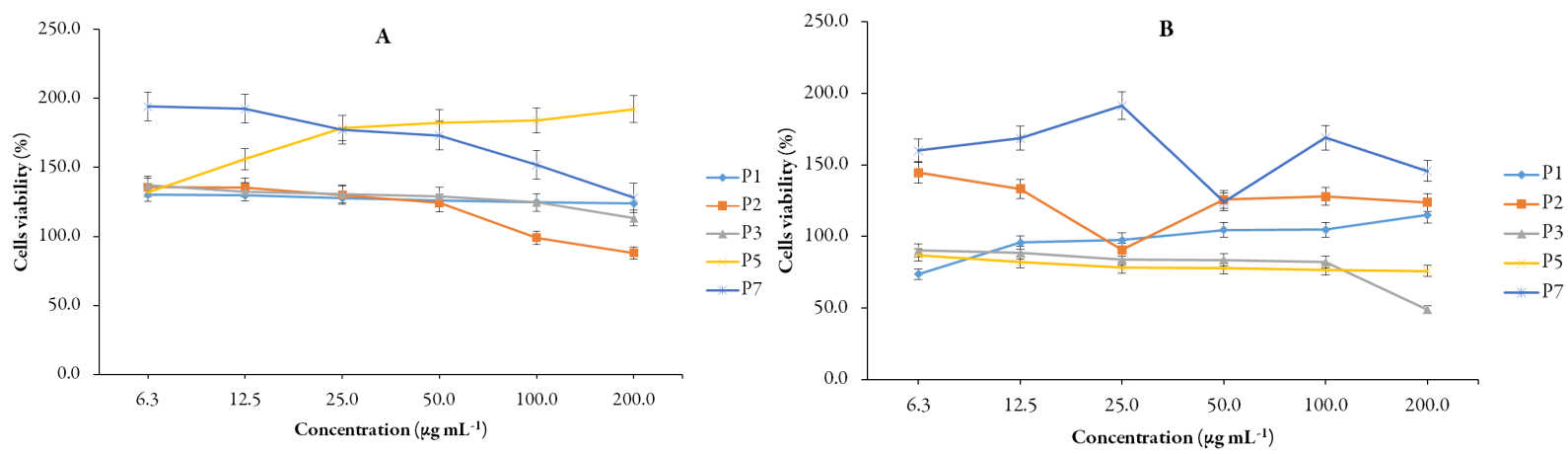

Fig. 2. Anticancer activity of methanolic fruit extracts of the wild Rubus idaeus populations: (A) $\mathrm{IC}_{50} / 24 \mathrm{~h} ;(\mathrm{B}) \mathrm{IC}_{50} / 48 \mathrm{~h}\left(\mu \mathrm{g} \mathrm{mL} \mathrm{m}^{-1}\right)$

Positive correlations also exist between AOA and flavonoids (P-value $=0.010<$ P-critical $=0.05)$. Negative correlations exist between MTT $24 \mathrm{~h}$ and AOA $(\mathrm{P}$-value $=$ $0.009<\mathrm{P}$-critical $=0.05)$, MTT $24 \mathrm{~h}$ and flavonoids (Pvalue $=0.036<\mathrm{P}$-critical $=0.05), \mathrm{AOA}$ and total phenols $(\mathrm{P}$-value $=0.000<\mathrm{P}$-critical $=0.05)$ and between flavonoid and phenol $(\mathrm{P}$-value $=0.014<\mathrm{P}$-critical $=0.05)$. By analysing the Pearson coefficient of correlation of the anticancer activity of the methanolic fruit extracts and the tested phytochemical parameters, it was found that there is no correlation.

In general, the most expressed biological activity (antimicrobial and anticancer) exhibited leaf extracts of the population with the highest content of tannins and anthocyanins (P1). It has been already reported on anticancer (Kong et al., 2003) and antimicrobial activity (Burdulis et al., 2009) of anthocyanins.

\section{Conclusions}

Based on the results presented in this research, wild raspberry from the central Balkan region - the territory of Serbia, can be recommended as a rich source of natural antioxidants, especially phenolic compounds. Also, wild raspberry leaves can be recommended as a supplement to tea blends in the treatment of various infections (especially for gastrointestinal disorders), due to their antimicrobial activity against $E$. coli. Raspberry leaf extracts were found to have mild anticancer activity, while the fruits did not show any anticancer activity. It is noticeable that the samples of plant populations from the high-altitude locality have more secondary metabolites and better biological activity. In addition to this fact, genetic material from the Serbian wild raspberry can be used as a basis for creating new varieties with improved trait characteristics.

\section{Acknowledgements}

Authors are grateful for support of Ministry of Education, Science and Technological Development of the Republic of Serbia for financing the Projects No. 3105.

\section{References}

Baby B, Antony P, Vijayan R (2017). Antioxidant and anticancer properties of berries. Critical Reviews in Food Science and Nutrition 1-17. https://doi.org/10.1080/10408398.2017.1329198.

Beekwilder J, Jonker H, Meesters P, Hall RD, van der Meer IM, Ric de Vos $\mathrm{CH}$ (2005). Antioxidants in raspberry: on-line analysis links antioxidant activity to a diversity of individual metabolites. Journal of Agricultural andFood Chemistry 53(9):3313-3320.

Benvenuti S, Pellati F, Melegari MA, Bertelli D (2004). Polyphenols, anthocyanins, ascorbic acid, and radical scavenging activity of Rubus, Ribes, and Aronia. Journal of Food Science 69(3):164169.

Bobinaitè R, Viškelis P, Venskutonis PR (2012). Variation of total phenolics, anthocyanins, ellagic acid and radical scavenging capacity in various raspberry (Rubus spp.) cultivars. Food Chemistry 132:1495-1501.

Boivin D, Blanchette M, Barrette S, Moghrabi A, Beliveau R (2007). Inhibition of cancer cell proliferation and suppression of TNF-induced 
366

activation of $\mathrm{NF} \times \mathrm{B}$ by edible berry juice. Anticancer Research 27(2):937-948.

Bowen-Forbes CS, Zhang Y, Nair MG (2012). Anthocyanin content, antioxidant, anti-inflammatory and anticancer properties of blackberry and raspberry fruits. Journal of Food Composition and Analysis 23(6):554-560.

Burdulis D, Sarkinas A, Jasutiene I, Stackevicené E, Nikolajevas L, Janulis V (2009). Comparative study of anthocyanin composition, antimicrobial and antioxidant activity in bilberry (Vaccinium myrtillus L.) and blueberry (Vaccinium corymbosum L.) fruits. Acta Poloniae Pharmaceutica 66(4):399-408.

Cao G, Sofic E, Prior RL (1997). Antioxidant and prooxidant behavior of flavonoids: structure-activity relationships. Free Radical Biology and Medicine 22(5):749-760.

Castillo NR (2006). Fingerprinting and genetic stability of Rubus using molecular markers. PhD Thesis, Oregon State University, The USA.

Çekiç Ç, Özgen M (2010). Comparison of antioxidant capacity and phytochemical properties of wild and cultivated red raspberries (Rubus idaeus L.).Journal of Food Composition and Analysis 23(6):540-544.

da Silva FL, Escribano-Bailón MT, Alonso JJ, Rivas-Gonzalo JC, SantosBuelga C (2007). Anthocyanin pigments in strawberry. LWT - Food Science and Technology 40(2):374382.

Dujmović Purgar D, Duralija B, Voća S, Vokurka A, Ercisli S (2012). A comparison of fruit chemical characteristics of two wild grown Rubus species from different locations of Croatia. Molecules 17(9):1039010398.

Durgo K, Belščak-Cvitanović A, Stančić A, Franekić J, Komes D (2012). The bioactive potential of red raspberry (Rubus idaeus L.) leaves in exhibiting cytotoxic and cytoprotective activity on human laryngeal carcinoma and colon adenocarcinoma. Journal of Medicinal Food 15(3):258-68.

Duval B, Shetty K, Thomas WH (1999). Phenolic compounds and antioxidant properties in the snow alga Chlamydomonas nivalis after exposure to UVlight. Journal of Applied Phycology 11(6):559-566.

Ghasemi K, Ghasemi Y, Ehteshamnia A, Nabavi SM, Nabavi SF, Ebrahimzadeh M A, Pourmorad F (2011). Influence of environmental factors on antioxidant activity, phenol and flavonoids contents of walnut (Juglans regia L.) green husks. Journal of Medicinal Plants Research 5(7):1128-1133.

Gramza-Michałowska A, Sidor A, Kulczyński B (2017). Berries as a potential anti-influenza factor - A review. Journal of Functional Foods 37:116 137.

Gudej J, Tomczyk M (2004). Determination of flavonoids, tannins and ellagic acid in leaves from Rubus L. species. Archives of Pharmacal Research 27(11):1114-1119.

Gülçin İ, Topal F, Çakmakçı R, Bilsel M, Gören AC, Erdogan U (2011). Pomological features, nutritional quality, polyphenol content analysis, and antioxidant properties of domesticated and 3 wild ecotype forms of raspberries (RubusidaeusL.).Journal of Food Science 76(4):585-593.

Holst L, Haavik S, Nordeng H (2004). Raspberry leaf - Should it be recommended to pregnant women? Complementary Therapies in Clinical Practice 15(4):204208.

Hosu A, Cristea VM, Cimpoiu C (2014). Analysis of total phenolic, flavonoids, anthocyanins and tannins content in Romanian red wines: Prediction of antioxidant activities and classification of wines using artificial neural networks. Food Chemistry 150:113-118.

Huang WY, Cai YZ, Zhang Y. Natural phenolic compounds from medicinal herbs and dietary plants: potential use for cancer prevention. Nutrition and Cancer 62(1):1-20.

Jakobek L, Seruga M, Seruga B, Novak I, Medvidovic-Kosanovic M (2009). Phenolic compound composition and antioxidant activity of fruits of Rubus and Prunus species from Croatia. International Journal of Food Science and Technology 44: 860-868.

Kadoma Y,Fujisawa S (2008). A comparative study of the radical-scavenging activity of the phenolcarboxylic acids caffeic acid, p-coumaric acid, chlorogenic acid and ferulic acid, with or without 2-mercaptoethanol, a thiol, using the induction period method. Molecules 13:2488-2499.

Khan MM, Haileselassie Y, Navis M, Cooper C, Sverremark-Ekström E, Nilsson AS (2017). Corrigendum: Morphologically distinct Escherichia coli bacteriophages differ in their efficacy and ability to stimulate cytokine release in vitro. Front Microbiology 7:2145.

Kong JM, Chia LS, Goh NK, Chia TF, Brouillard R (2003). Analysis and biological activities of anthocyanins. Phytochemistry 64(5):923-933.

Konić-Ristić A, Šavikin K, Zdunić G, Janković T, Juranić Z, Menković N, Stanković I (2011). Biological activity and chemical composition of different berry juices. Food Chemistry 125:1412-1417.

Lam-Himlin D, Montgomery E, Torbenson M (2012). Non-neoplastic and neoplastic disorders of the appendix. Gastrointestinal and Liver Pathology 2:257-296.

Liu CH, Chiu CH, Wang SW, Cheng W (2012). Dietary administration of the probiotic, Bacillus subtilis E20, enhances the growth, innate immune responses, and disease resistance of the grouper, Epinephelus coioides. Fish Shellfish Immunology 33(4):699-706.

Määttä-Riihinen KR, Kamal-Eldin A, Törrönen AR (2014). Identification and quantification of phenolic compounds in berries of Fragaria and Rubus species (family Rosaceae). Journal of Agricultural and Food Chemistry 52(20):6178-6187.

Marulanda ML, López AM, Aguilar SB (2007). Genetic diversity of wild and cultivated Rubus species in Colombia using AFLP and SSR markers. Crop Breeding and Applied Biotechnology 7(3):242-252.

Menković N, Šavikin K, Zdunić G, Milosavljević S, Živković J (2014). Medicinal Plants in Northern Montenegro: Traditional Knowledge, Quality, and Resources. In: Pieroni A, Quave CL (Eds). Ethnobotany and Biocultural Diversities in the Balkans. New York, Springer pp 197228.

Mikulić-Petkovsek M, Schmitzer V, Slatnar A, Stampar F, Veberić R(2012). Composition of sugars, organic acids, and total phenolics in 25 wild or cultivated berry species. Journal of Food Science 77(10):10641070.

Mosmann T (1983). Rapid colorimetric assay for cellular growth and survival: application to proliferation and cytotoxicity assays. Journal of Immunology Methods 65(1-2):55-63.

Patel AV, Rojas-Vera J, Dacke CG (2004). Therapeutic constituents and actions of Rubus species. Current Medicinal Chemistry 11(11):15011512

Quettier-Deleu C, Gressier B, Vasseur J, Dine T, Brunet C, Luyckx M, Cazin M, Cazin JC, Bailleul F, Trotin F (2000). Phenolic compounds 
and antioxidant activities of buckwheat (Fagopyrum esculentum Moench) hulls and flour. Journal of Ethnopharmacology 72(1-2):3542

Rao AV, Snyder DM (2010). Raspberries and human health: a review. Journal of Agricultural and Food Chemistry 58(7):3871-3883.

Rauha JP, Remes S, Heinonen M, Hopia A, Kähkönen M, Kujala T, Pihlaja K, Vuorela H, Vuorela P (2000). Antimicrobial effects of Finnish plant extracts containing flavonoids and other phenolic compounds. International Journal of Food Microbiology 56(1):3-12.

Rowe B (1979). The role of Escherichia coli in gastroenteritis. Clinics in Gastroenterology 8(3):625-644.

Sarker SD, Nahar L, Kumarasamy Y (2007). Microtitre plate-based antibacterial assay incorporating resazurin as an indicator of cell growth, and its application in the in vitro antibacterial screening of phytochemicals. Methods 42(4):321-324.

Seeram NP, Adams LS, Zhang Y, Lee R, Sand D, Scheuller HS, Heber D (2006). Blackberry, black raspberry, blueberry, cranberry, red raspberry, and strawberry extracts inhibit growth and stimulate apoptosis of human cancer cells in vitro. Journal of Agricultural and Food Chemistry 54(25):9329-9339.

Seeram NP (2008). Berry fruits for cancer prevention: current status and future prospects. Journal of Agricultural and Food Chemistry 56(3):630-635.

Stanković MS, Petrović M, Godjevac D, Stevanović ZD (2015). Screening inland halophytes from the central Balkan for their antioxidant activity in relation to total phenolic compounds and flavonoids: Are there any prospective medicinal plants? Journal of Arid Environments 120:26-32.
Sun J, Kato I (2016). Gut microbiota, inflammation and colorectal cancer. Genes \& Diseases 3:130-143.

Takao T, Kitatani F, Watanabe N, Yagi A, Sakata K (1994). A simple screening method for antioxidants and isolation of several antioxidants produced by marine bacteria from fish and shellfish. Bioscience, Biotechnology and Biochemistry 58(10):1780-1783.

Tosun M, Ercisli S, Karlidag H, Sengul M (2009). Characterization of red raspberry (Rubus idaeus L.) genotypes for their physicochemical properties. Journal of Food Sciences 74(7):575-579.

Trivedi AK, Verma SK, Tyagi RK (2016). Variability in morphophysiological traits and antioxidant potential of Rubus species in Central Himalayan Region. Industrial Crops and Products 82:1-8.

Veberić R, Slatnar A, Bizjak J, Stampar F, Mikulić-Petkovsek M (2015). Anthocyanin composition of different wild and cultivated berry species. LWT-Food Science and Technology 60(1):509-517.

Vyas P, Kalidindi S, Chibrikova L, Igamberdiev AU, Weber JT (2013). Chemical analysis and effect of blueberry and lingonberry fruits and leaves against glutamate-mediated excitotoxicity. Journal of Agricultural and Food Chemistry 61(32):7769-7776.

Wang SY, Lin HS. (2000) Antioxidant activity in fruits and leaves of blackberry, raspberry, and strawberry varies with cultivar and developmental stage. Journal of Agricultural and Food Chemistry 48(2):140-146.

Wootton-Beard PC, Moran A, Ryan L (2011). Stability of the total antioxidant capacity and total polyphenol content of 23 commercially available vegetable juices before and after in vitro digestion measured by FRAP, DPPH, ABTS and Folin - Ciocalteu methods. Food Research International $44(1): 217-224$. 